\title{
Association of bovine papillomavirus type 2 (BPV-2) and urinary bladder tumours in cattle from the Azores archipelago
}

\author{
Ana R. Resendes ${ }^{a, *}$, Sante Roperto ${ }^{b}$, Francesca Trapani ${ }^{b}$, Chiara Urraro ${ }^{b}$, Armindo Rodrigues ${ }^{a}$, \\ Franco Roperto ${ }^{\mathrm{b}}$, Giuseppe Borzacchiello ${ }^{\mathrm{b}}$ \\ ${ }^{a}$ Center for Research in Natural Resources (CIRN), University of the Azores, Apt 1422, 9501-855 Ponta Delgada, Portugal \\ ${ }^{\mathrm{b}}$ Department of Pathology and Animal Health, Faculty of Veterinary Medicine, Naples University Federico II, Via F. Delpino, 1-80137 Naples, Italy
}

\section{A R T I C L E I N F O}

\section{Article history:}

Received 18 December 2008

Accepted 3 February 2010

\section{Keywords:}

BPV-2

E5 oncoprotein

PCR

Cattle

Bracken fern

Chronic enzootic haematuria

\begin{abstract}
A B S T R A C T
Urinary bladder tumours in cattle are caused by chronic ingestion of bracken fern and BPV-1/2 infection. The objective of the present study was to assess if BPV-2 was present in urinary bladder lesions from cattle with chronic enzootic haematuria (CEH) from the Azores archipelago (Portugal), in order to gain further information regarding the epidemiologic distribution of this virus. Samples were analysed using PCR specific primers for BPV-2 DNA and an immunohistochemistry for BPV E5 oncoprotein detection. We found a $28 \%$ incidence rate of BPV-2 DNA in different types of tumours and cystitis cases (13 out of 46 samples). Tested positive samples for PCR were also positive for the viral E5 oncoprotein; protein immunolabeling was mainly detected within the cytoplasm of urothelial cells, displaying a juxtanuclear distribution. This is the first report of BPV-2 detection in urinary bladder tumours associated with CEH in cattle from the Azores archipelago.
\end{abstract}

(c) 2010 Elsevier Ltd. All rights reserved.
Bovine papillomavirus type 2 (BPV-2) is a Deltapapillomavirus, with a non-enveloped icosahedral structure and a double-stranded covalently closed circular DNA, with a genome of approximately 8000 base pairs (Campo, 2006). In cattle, urinary bladder carcinogenesis is multifactorial caused by a synergetic mechanism between BPV-1/2 infection and chronic ingestion of bracken fern (genus Pteridium) (Campo, 2006; Campo et al., 1992). The casual association of BPV-2 and urinary bladder tumours has been reported worldwide in cattle from Italy, Scotland, Romania, and Brazil (Balcos et al., 2008; Borzacchiello et al., 2003; Campo et al., 1992; Wosiacki et al., 2006). Urinary bladder tumours are endemic in the Azores archipelago (Carvalho et al., 2006; Pinto et al., 2003) however, association with BPV(s) infection has not been reported to date. The E5 is the major BPV-1/2 oncoprotein and has been found to be expressed in bovine BPV-associated urinary bladder and gastrointestinal tumours, suggesting its participation in carcinogenesis (Bohl et al., 2001; Borzacchiello et al., 2003). The aim of this study was to investigate the presence of BPV-2 infection in urinary bladder tumours from cattle with chronic enzootic haematuria (CEH) bred in the Azores archipelago.

A total of forty-two female cows aged between 3.5 and 12 years-old were included in this study. Animals were bred at different farms located in São Miguel Island at the Azores archipelago (Portugal). Cattle livestock at the Azores often grazes in

\footnotetext{
* Corresponding author. Tel.: +351 296650 111x1109; fax: +351 296650100 .

E-mail address: resendes.ana@gmail.com (A.R. Resendes).
}

pastures and landscapes where bracken fern (Pteridium aquilinum) is abundant (Illas et al., 2005; Silva, 2001). At the slaughterhouse cows were euthanized, bled and after the urinary bladder examined for the presence of macroscopic lesions. From each cow one to two samples of the urinary bladder were collected for further investigation. Four cows had duplicate samples from multifocal urinary bladder lesions (a total of 46 lesions were included) (Table 1). Tissues were fixed by immersion in $10 \%$ neutral-buffered formalin and routinely processed and stained with haematoxylin and eosin (HE) for histological examination. PCR was used to screen 46 urinary bladder samples for BPV-2 DNA. Extraction was done from $20 \mu \mathrm{m}$ of formalin-fixed paraffin-embedded samples using the DNeasy Tissue Kit (Qiagen $^{\circledR}$ ) and a previously standardized methodology (Roperto et al., 2008). BPV-2 specific primers for the E5 region were used for amplification in a total of 200-300 ng of purified DNA per PCR reaction (Roperto et al., 2008). To evaluate the adequacy of the DNA, a control PCR for bovine $\beta$-actin sequence was performed using previously published primers (Colitti et al., 2004). For each PCR reaction, a blank sample consisting of the reaction mixture without DNA, from a normal cow urothelium, and a positive sample consisting of BPV-2 clone DNA were included as negative and positive controls, respectively. Further, E5 BPV oncoprotein expression was assessed in twelve PCR positive samples by an immunohistochemistry (no more tissue was available to screen one of the two cystitis cases). Briefly, tissue sections were stained using a polyclonal sheep anti-E5 antibody 
Table 1

Cow pool with lesions distribution and PCR results for BPV-2 DNA detection per cow.

\begin{tabular}{|c|c|c|}
\hline Cow $n^{\circ}$ & PCR BPV-2 & Histopathology \\
\hline $\mathrm{CW} 1^{\mathrm{a}}$ & Neg & $\mathrm{UC}+\mathrm{P}$ \\
\hline CW2 & + & S \\
\hline CW3 & Neg & UC \\
\hline CW4 & + & $\mathrm{S}$ \\
\hline $\mathrm{CW}^{\mathrm{a}}$ & + & $\mathrm{UC}+\mathrm{H}$ \\
\hline CW6 & Neg & $\mathrm{P}$ \\
\hline CW7 & Neg & UC \\
\hline CW8 & Neg & UC \\
\hline CW9 $9^{\mathrm{a}}$ & + & $\mathrm{MCH}+\mathrm{MCH}$ \\
\hline CW10 & + & $\mathrm{Cy}$ \\
\hline CW11 & Neg & UC \\
\hline CW12 & + & Сy \\
\hline CW13 & Neg & $\mathrm{P}$ \\
\hline CW14 & Neg & UC \\
\hline CW15 & Neg & $P$ \\
\hline CW16 & Neg & UC \\
\hline CW17 & Neg & UC \\
\hline CW18 & Neg & $P$ \\
\hline CW19 & Neg & UC \\
\hline CW20 & Neg & $\mathrm{P}$ \\
\hline CW21 & Neg & UC \\
\hline CW22 & Neg & $\mathrm{P}$ \\
\hline CW23 & Neg & UC \\
\hline CW24 & + & UC \\
\hline$C W 25^{a}$ & + & $\mathrm{UC}+\mathrm{H}$ \\
\hline CW26 & + & UC \\
\hline CW27 & Neg & $\mathrm{H}$ \\
\hline CW28 & $\mathrm{Neg}$ & UC \\
\hline CW29 & Neg & UC \\
\hline CW30 & Neg & UC \\
\hline CW31 & Neg & UC \\
\hline CW32 & Neg & UC \\
\hline CW33 & + & UC \\
\hline CW34 & Neg & $\mathrm{H}$ \\
\hline CW35 & Neg & UC \\
\hline CW36 & $\mathrm{Neg}$ & UC \\
\hline CW37 & Neg & $\mathrm{S}$ \\
\hline CW38 & Neg & UC \\
\hline CW39 & + & UC \\
\hline CW40 & Neg & $\mathrm{MCH}$ \\
\hline CW41 & Neg & UC \\
\hline CW42 & Neg & UC \\
\hline
\end{tabular}

UC, urothelial carcinoma; P, papilloma; S, sarcoma; $\mathrm{H}$, haemangioma; $\mathrm{MCH}$, mixed carcinoma and haemangioma).

a Cows with duplicate samples.

(gift from M.S. Campo, Institute of Comparative Medicine, Glasgow) (Borzacchiello et al., 2007) by the streptavidin-biotin (LSAB) immunohistochemical method as previously described (Balcos et al., 2008; Borzacchiello et al., 2007). As negative controls, a section of normal bovine urinary bladder mucosa, negative for BPV-2 DNA detection by PCR, was used (see Fig. 2a); further the primary antibody was replaced in all tested sections by an irrelevant antibody (see Fig. 2b).

After histologic evaluation urinary bladder lesions were classified as follows: urothelial carcinomas (58.7\%), papillomas (15.2\%), haemangiomas (8.7\%); sarcomas (6.5\%), cystitis (4.3\%), and mixed urothelial carcinoma and haemangiomas tumours (6.5\%) (Table 2). A total of 13 urinary bladder samples (28.2\%), corresponding to different animals, were positive for BPV-2 DNA detection (Tables 1 and 2). BPV-2 DNA was found associated with carcinomas (46.1\%), haemangiomas (15.3\%), mixed carcinoma and haemangiomas tumours (7.6\%), sarcomas (15.3\%) and cystitis (15.3\%) (Table 2). E5 expression was immunohistochemically detected in all tested tumours and in the cystitis tested case. Immunolabeling was found both diffusely and/or discontinuously distributed in low to moderate amounts in the urothelium of carcinomas and in mesenchymal tumours. In urothelial carcinomas the amount of stained cells was higher in the suprabasal cell layer (Fig. 1a). Immunoreaction was intracytoplasmic, often with a juxtanuclear distribution (Fig. 1b). In dysplastic and apparently normal urothelium the amounts of E5 immunoreaction were low. In haemangioma's mesenchymal and endothelial cells positive labeling was scarce).

BPV-1/2 association with urinary bladder tumours in cows with $\mathrm{CEH}$ has been reported from most geographic areas where this disease is present. We now report for the first time the occurrence of BPV-2 in urinary bladder tumours from cattle grazed in the Azores archipelago (Portugal). Our results further support the casual relationship between urinary bladder carcinogenesis and BPV-1/2 infection and corroborates the wide spread of this virus. We detected BPV-2 using both PCR, with specific primers for BPV-2 DNA, and an immunohistochemistry for detection of the E5 viral oncoprotein in tissue sections. Both the viral DNA and protein expression were detected, which confirmed BPV-2 infection of the urinary bladder. BPV-2 infection prevalence was $28.2 \%$ in different types of urinary bladder lesions. We found two cystitis, corresponding to two cows, positive for BPV-2 DNA detection, which is intriguing; BPV has been found present in sarcoma's inflammatory lesions in horses (Yuan et al., 2007a,b), however further research is necessary to clarify the relationship between BPV infection and inflammation. Urinary bladder tumours are endemic in the Azores, accounting for an important economic impact, mainly because favorable climacteric conditions for bracken fern proliferation exist in this geographic area and cattle often graze in pastures and landscapes where bracken is present and abundant (Carvalho et al., 2006; Illas et al., 2005; Pinto et al., 2003; Silva, 2001). The rate of BPV-2 detection we found was lower than what we expected, since in other reports detection rates varied from $46 \%$ to $77 \%$. It is possible there exists geographic variations in the prevalence of BPV infection, however another possible explanation may be the variation in tumour collection methodology, since formaldehyde causes DNA denaturation and the lowest rates of detection are mostly detected in studies using tumours stored in formaldehyde. Our results respect to the E5 oncoprotein expression were in agreement with other reports (Balcos et al., 2008; Bohl et al., 2001; Borzacchiello et al., 2003).

In conclusion, this study demonstrates BPV-2 infection in urinary bladder tumours and inflammatory lesions in cattle with CEH from the Azores archipelago.

Table 2

Histological classification of urinary bladder lesions and detection of BPV-2 DNA

\begin{tabular}{|c|c|c|}
\hline Urinary bladder lesions & Number/rate & BPV-2 DNA positive \\
\hline Urothelial carcinoma (UC) & $27(58.72 \%)$ & $6(46.1 \%)$ \\
\hline Haemangioma $(\mathrm{H})$ & $4(8.7 \%)$ & $2(15.3 \%)$ \\
\hline Sarcoma $(S)$ & $3(6.5 \%)$ & $2(15.3 \%)$ \\
\hline Mixed haemangioma and carcinoma (MCH) & $3(6.5 \%)$ & $1(7.6 \%)$ \\
\hline Papilloma $(\mathrm{P})$ & $7(15.2 \%)$ & $0(0 \%)$ \\
\hline Cystitis (Cy) & $2(4.3 \%)$ & $2(15.3 \%)$ \\
\hline Total & $46(100 \%)^{a}$ & $13(100 \%)$ \\
\hline
\end{tabular}

\footnotetext{
a Four cows had duplicate tumour samples, corresponding: cow 1 (UC + P); cow 2 (UC + H); cow $3(\mathrm{MCH}+\mathrm{MCH})$; cow $4(\mathrm{C}+\mathrm{H})$.
} 

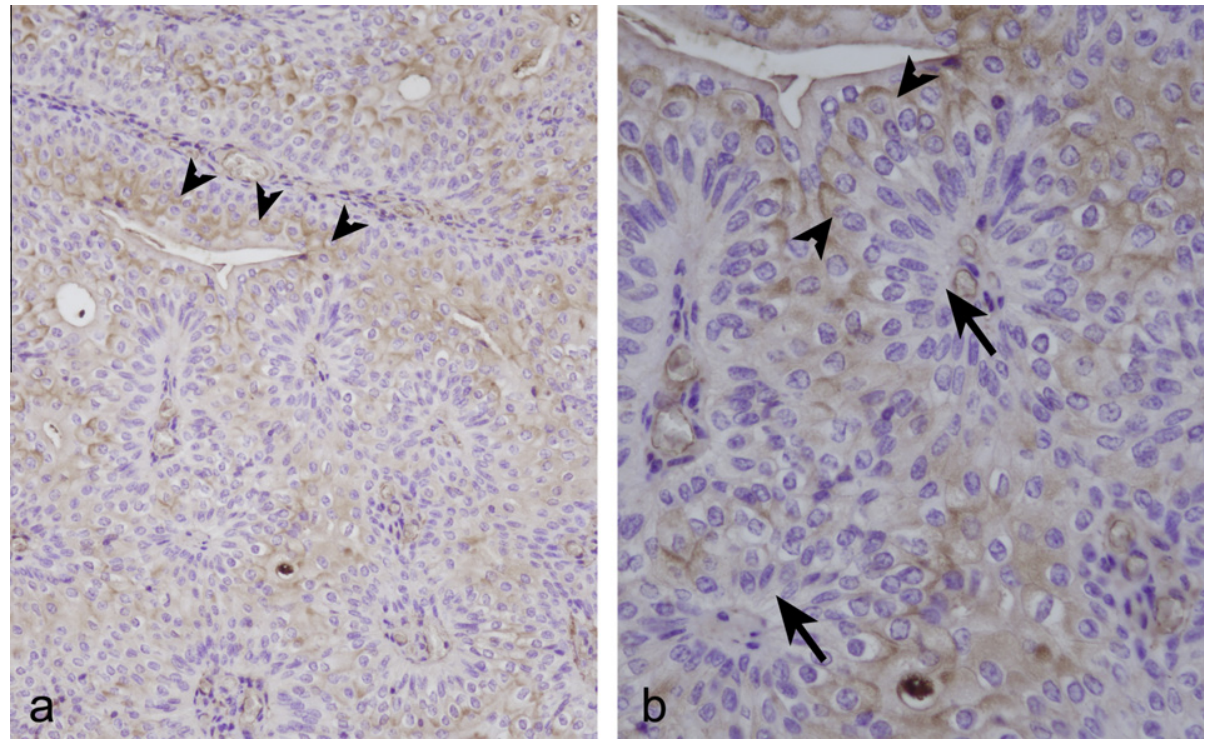

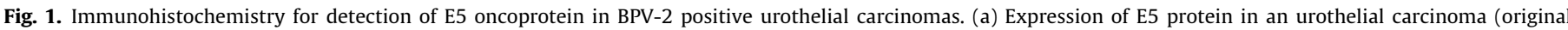

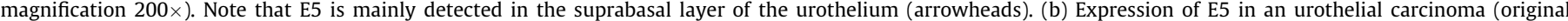

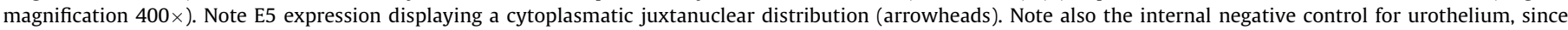
many basal cells are not stained for E5 protein (arrows).
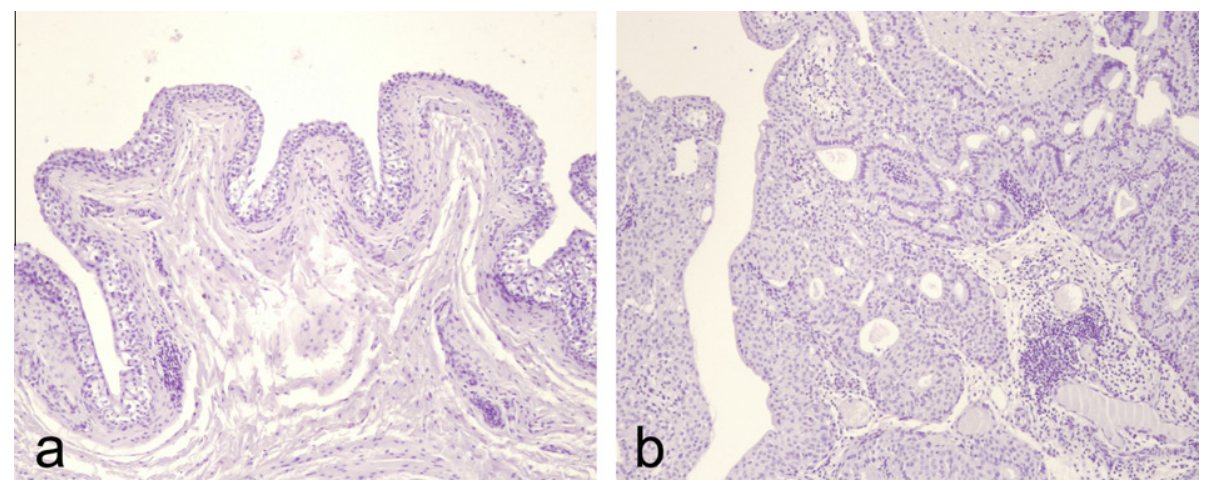

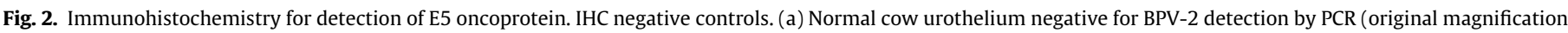
$100 \times$ ). (b) An urothelial carcinoma negative for BPV-2 DNA detection and without E5 oncoprotein expression (original magnification $200 \times$ ).

\section{Acknowledgments}

The authors would like to thank excellent technical assistance of Paulo Melo and Teresa Cymbron from CIRN and the Department of Biology, University of the Azores for samples collection at the slaughterhouse. The first author Ana Resendes was supported by a Postdoctoral grant from DRCT (Direcção Regional da Ciência e Tecnologia, Governo dos Açores, Portugal) n FRCT/2008/112/004 and a scholarship for researchers mobility from Università degli Studi di Napoli Federico-II (Italia). This work was founded by project Ministero dell'Istruzione, Università e Ricerca scientifica (MIUR) - PRIN n ${ }^{\circ}$ prot. 2006078044 - 2006/2008 and Legge Regionale $\mathrm{N}^{\circ} 5$ (2006) from Regione Campania (Italia) and the CIRN (Centro de Investigação em Recursos Naturais, Universidade dos Açores) (Portugal).

\section{References}

Balcos, L.G., Borzacchiello, G., Russo, V., Popescu, O., Roperto, S., Roperto, F., 2008. Association of bovine papillomavirus type-2 and urinary bladder tumours in cattle from Romania. Research in Veterinary Science 85, 145-148.

Bohl, J., Hull, B., Vande Pol, S.B., 2001. Cooperative transformation and coexpression of bovine papillomavirus type 1 E5 and E7 proteins. Journal of Virology 75, 513521
Borzacchiello, G., Iovane, G., Marcante, M.L., Poggiali, F., Roperto, F., Roperto, S. Venuti, A., 2003. Presence of bovine papillomavirus type 2 DNA and expression of the viral oncoprotein E5 in naturally occurring urinary bladder tumours in cows. Journal of General Virology 84, 2921-2926.

Borzacchiello, G., Russo, V., Spoleto, C., Roperto, S., Balcos, L., Rizzo, C., Venuti, A. Roperto, F., 2007. Bovine papillomavirus type-2 DNA and expression of E5 and E7 oncoproteins in vascular tumours of the urinary bladder in cattle. Cancer Letters 250, 82-91.

Campo, M.S., 2006. Bovine papillomavirus: old system, new lessons? In: Campo M.S. (Ed.), Papillomavirus Research from Natural History to Vaccines and Beyond. Caister Academic Press, Norfolk, pp. 373-383.

Campo, M.S., Jarrett, W.F., Barron, R., O'Neil, B.W., Smith, K.T., 1992. Association of bovine papillomavirus type 2 and bracken fern with bladder cancer in cattle. Cancer Research 52, 6898-6904.

Carvalho, T., Pinto, C., Peleteiro, M.C., 2006. Urinary bladder lesions in bovine enzootic haematuria. Journal of Comparative Pathology 134, 336-346.

Colitti, M., Wilde, C.J., Stefanon, B., 2004. Functional expression of bcl-2 protein family and AIF in bovine mammary tissue in early lactation. Journal of Dairy Research 71, 20-27.

Illas, X., Silva, L., Cordeiro, N., Martínez, A., Pinto, C., 2005. Distribuição e abundância do feto comum Pteridium aquilinum, na ilha do Pico. In: Relatório da XII Expedição Científica do Departamento de Biologia - Pico. Department of Biology, University of the Azores, p. 231.

Pinto, C., Januário, T., Geraldes, M., Lauren, D.R., Smith, B.L., Robinson, R.C., 2003. Bovine enzootic haematuria on Sao Miguel Island, Azores. In: Acamovic, T. Pennycott, T.W. (Eds.), Poisonous Plants and Related Toxins. CABI Publishing Wallingford, Oxon, UK, pp. 564-574.

Roperto, S., Brun, R., Paolini, F., Urraro, C., Russo, V., Borzacchiello, G., Pagnini, U., Raso, C., Rizzo, C., Roperto, F., Venuti, A., 2008. Detection of bovine 
papillomavirus type 2 in the peripheral blood of cattle with urinary bladder tumours: possible biological role. Journal of General Virology 89, 3027-3033.

Silva, L., 2001. Plantas invasoras no Arquipélago dos Açores: caracterização geral e estudo de um caso, Clethra arborea Aiton (Clethraceae). PhD thesis. University of the Azores, Ponta Delgada.

Wosiacki, S.R., Claus, M.P., Alfieri, A.F., Alfieri, A.A., 2006. Bovine papillomavirus type 2 detection in the urinary bladder of cattle with chronic enzootic haematuria. Memórias do Instituto Oswaldo Cruz 101, 635-638.
Yuan, Z., Gallagher, A., Gault, E.A., Campo, M.S., Nasir, L., 2007a. Bovine papillomavirus infection in equine sarcoids and in bovine bladder cancers. Veterinary Journal 174, 599-604.

Yuan, Z., Philbey, A.W., Gault, E.A., Campo, M.S., Nasir, L., 2007b. Detection of bovine papillomavirus type 1 genomes and viral gene expression in equine inflammatory skin conditions. Virus Research 124, 245-249. 